\title{
LEVELS OF SOCIAL INTEGRATION OF INTERNALLY DISPLACED PERSONS IN THE HOST COMMUNITY
}

\author{
Olena Chuiko, ${ }^{1}$ Oleksandra Fedorenko ${ }^{2}$
}

Taras Shevchenko National University of Kyiv, Ukraine

\begin{abstract}
The purpose of the article is to present the results of an empirical study on the level of social integration of internally displaced persons in the host community. Social integration is seen as an active process involving both parties: migrants and the host population. The process is continuous, so the focus is on the degree of integration of internally displaced persons, reflected at three levels, high, medium and low. The degree of social integration of IDPs in the local community is an aggregate indicator of socio-economic, socio-psychological, cultural-communicative and socio-political elements. The study applied a set of standardised methods, as well as correlation, factor and variance analysis (Fisher's criterion). The results show a positive tendency for integration by the vast majority of internally displaced persons who participated in the study: only 26 respondents (12.9\%) had a low level, 121 respondents $(60.2 \%)$ had a medium level, and 54 respondents had a high level (26.9\%).

KEY WORDS: social integration, integration levels, internally displaced persons in Ukraine, host community.
\end{abstract}

JEL CODES: I 31, I 38, O 15, R 23

DOI:

\section{Introduction}

Hostilities have continued in the east of Ukraine for six years, due to which nearly one and a half million people have been forced to migrate to a new safe place of residence. As of 10 February 2020, the registered number of internally displaced persons from the temporarily occupied regions of Donetsk and Luhansk, and the Autonomous Republic of Crimea, was 1,440,167 people (according to the Ministry of Social Policy of Ukraine 2020). Resettlement is taking place in different parts of the country: Kyiv, Kharkiv, Lviv, Odessa, and other regions. It is clear that the large scale of internal migration has led to the emergence of numerous social problems, both for migrants and for the host population. Furthermore, the state has been tasked with developing a social policy to integrate the newly arrived citizens into local communities.

Since the beginning of the conflict in eastern Ukraine and the conduct of the anti-terrorist operation, the government and the cabinet of ministers of Ukraine have developed a number of laws and regulations to regulate the social policy of the state regarding internally displaced people. The main law guaranteeing respect for the rights, freedoms and legal interests of internally displaced persons is the Law of Ukraine of 20 October 2014 No 1706-VII 'On Ensuring the Rights and Freedoms of Internally Displaced Persons', which consists of 20 articles. The first article states: 'An internally displaced person (IDP) is a citizen of Ukraine, a foreigner or a stateless person who resides legally on Ukrainian territory and is entitled to permanent residence in Ukraine, who has been forced to leave their place of residence as a result of or for the purpose of avoidance of the negative effects of armed conflict, temporary occupation, widespread manifestations of violence, human rights violations, and natural or man-made emergencies.'

1 Olena Chuiko is a doctor of psychological science, professor and head of the Department of Social Rehabilitation and Social Pedagogy at Taras Shevchenko National University of Kiev, Ukraine. Research interests: social rehabilitation techniques. Email: chuiko_ov@ukr.net

2 Oleksandra Fedorenko is a postgraduate student in the Department of Social Rehabilitation and Social Pedagogy at Taras Shevchenko National University of Kiev, Ukraine. Research interests: social rehabilitation techniques. E-mail: ssoldatovaa@gmail.com 
This law corresponds with international instruments regarding the rights and protection of internally displaced persons, in particular the UN Convention on the Status of Refugees (1951), Guiding Principles on Internal Displacement (1998), and UN General Assembly materials of 14 November 2017 'Protection and Assistance to Internally Displaced Persons', which were adopted in 2018 as a three-year plan by 2020.

One of the key UN Guidelines on Internal Displacement (1998) is that displacement should take no longer than the circumstances dictate. Following these principles, in April 2016, the government of Ukraine established the Ministry of Temporarily Occupied Territories (MTOT) and Internally Displaced Persons of Ukraine, whose purpose was to formulate and implement a state policy in the area of reconstruction and peace building in conflict-affected areas and territories, temporarily occupied territories of Ukraine. In 2017, the Strategy for the Integration of Internally Displaced Persons and the Implementation of Long-Term Solutions for Internal Displacement for the Period up to 2020 was approved. It states that the basic conditions for the socio-economic integration of IDPs are the availability of housing, a regular income and employment.

Problem. Thus, the search for ways to solve the problem of the social integration of internally displaced persons remains relevant in Ukraine. Despite the existing legal framework and international recommendations on this issue, the conditions and levels of social integration of internally displaced persons in host communities remain insufficiently studied, and therefore there is no comprehensive approach to addressing this problem locally. In our view, this slows down the systematic solution and forecasting of social integration problems at the national, regional and local levels, as well as the process of developing optimal social policies for migrating individuals.

The subject is the process of social integration of internally displaced persons in the host community.

The purpose of the article is to present the empirical study results, which allow us to define three levels of social integration of internally displaced persons in the host community.

Research objectives: to make a theoretical analysis of the problem of integration of internally displaced persons in Ukraine; to present the author's research model of social integration of IDPs in the community and its structure; to describe the results of the empirical study of IDPs' levels of integration and the conditions that affect each level.

Methods. The study used a set of standardised techniques, as well as correlation, factor and variance analysis (Fisher's criterion).

\subsection{Theoretical foundations of the study}

United Nations (UN) experts presented in the World Migration Report (2000) a classification of migrants, which included five reasons for resettlement, namely: educational purposes, labour migration, family reunification, residency, and forced displacement (refugees, asylum seekers).

Internally displaced persons in Ukraine are migrants who have been forced to change their place of residence in order to save their lives because of military conflict in their area, unlike refugees, who in most cases are victims of political, religious or ethnic persecution, and are forced to cross a state border (Al-Sharmani 2004).

Internal displacement is a kind of migration in which migrants for different reasons change their place of residence without crossing a state border. S. Castles (2001) refers to this type of migration as internal movement within the country.

In accordance with the Guiding Principles of Internal Displacement (1998), the most common ways of addressing IDPs' problems are returning and reintegrating into their original habitats, or, if this is not possible or would endanger life, relocation to other safe parts of the country. As has been noted by researchers (Jacobsen 2001; Duncan 2005), these strategies are commonly used in cases where displacement is considered temporary. However, in Ukraine, as in many other countries, such as Sudan, Bosnia and the Central African Republic, it is not possible to solve quickly the problem that caused the internal migration. That is why international experience shows that the strategy of integrating migrants into host communities is a long-term solution.

The fundamental definition of the concept of 'integration' is presented in the works of T. Parsons, by which he understood 'such structures and processes by which relations between parts of the social system people who play certain roles, collectives and components of normative standards, are ordered in a way 
which ensures their harmonious functioning in the corresponding relations with each other in the system' (Parsons 1972: 364). Therefore, we view integration as a 'balancing act' between internally displaced people and the local community.

Instead, it is quite a challenge to determine what mechanisms and methods lead to this harmonisation. Thus, in the study by A. Ager and A. Strang on building a model of integration of migrants, an inductive method of conceptualising what is 'successful' integration was used. The structure of integration offers ten basic elements that shape its common understanding: access to employment, housing, education and health; citizenship and the rights of migrants; processes of social dialogue within the community; and structural barriers relating to language, culture and the local environment (Ager, Strang 2008: 191). That is, it includes all the basic spheres of human life in the new place of residence.

Researchers at the International Organization for Migration (IOM 2011) define integration as mutual adaptation between the host community and migrants, both as individuals and as a group. The analysis includes housing indicators, job security, wages, social assistance, frequency of communication with neighbours, command of the state language, participation in elections, and identification and respect for the core set of values that bind migrants and host communities for common purposes. However, there are different conditions for successful integration in each country, as the list of problems and local peculiarities differs.

For example, according to a survey in Georgia of 3,000 IDP families, about 68\% of IDPs interacted with the locals, but mostly those who lived not in urban centres but in private residences (Nadareishvili, Tsakadze 2008). A qualitative survey of IDPs in urban centres showed that, despite the presence of other displaced persons, they felt isolated and alone. That is, mutual integration into the host community may also be affected by the type of settlement (large city or private sector).

Depending on the scientific approach, research into the integration process may also focus on different data:

- the study of individual socio-psychological characteristics of internally displaced persons themselves;

- the study of the community in which IDPs are integrated;

- the consideration of infrastructure options of cities where IDPs have moved;

- the comparison of IDPs' relations with the host population and the actions of the authorities to support IDPs, etc.

The CEDOS think tank (analytical centre) has developed the Integrated Displacement Integration Index as a tool to evaluate and measure opportunities for the integration of IDPs into resettlement cities, that is, the ability of these cities to reintegrate IDPs. The indicators include access to the urban infrastructure, the capacity of local authorities, and interaction with the local authorities (CEDOS 2018).

The Desk Research of Surveys (2018) compiled by the Ukrainian researchers I. Volosevich and T. Kostyuchenko for the United Nations High Commission for Refugees (UNHCR) outlines the main factors that influence IDPs' decision to integrate into local communities. These include: good living conditions (67\% of respondents), good work (65\%), access to schools and hospitals (56\%), acceptance by the local community (38\%), other displaced persons' decisions to stay (35\%).

The results of the studies conducted in Ukraine show different figures regarding the number of 'integrated' displaced persons: from $33 \%$ to $68 \%$. For example, a survey by the International Organization for Migration (IOM) in June 2017 showed 68\% of 'integrated' IDPs, compared with 56\% in March 2017. Instead, a survey by the IFES International Fund showed a figure of $60 \%$, and the World Bank only $33 \%$. These results indicate, on one hand, an increase in the number of IDPs integrated, and on the other, the lack of a unified methodology for integration studies.

In the latest brief by the United Nations on Ukraine (2019), effective ways to integrate internally displaced persons were identified, including the following: 1) the registration of IDPs should capture not only the legal status of the individual, but also the important needs of the individual as a whole; 2) increasing the amount of financing to solve IDP problems; 3) giving IDPs the right to vote in elections at all levels; 4) increasing the amount of affordable housing for internally displaced persons. 
Thus, an analysis of the data shows that research into the integration of internally displaced persons into host communities is currently a fairly common research practice that requires improvement in its qualitative parameters.

\subsection{Research methodology}

The analytical review provided in this section is a meta-research model that enables the conceptualisation of the social integration of internally displaced persons in a particular local community (Fedorenko 2018). This model is based on the concept of the protection of human rights for the problem of displaced persons, and is built with the inclusion of four main segments that reflect the human rights areas of displacement in new local communities. At the heart of this model is an internally displaced person who meets the needs for the application of rights in each of the four spheres of social life, namely the following:

1) socio-psychological: reflects the right of internally displaced persons to freedom to decide on the choice of residence, return, integration or resettlement in other parts of the country;

2) cultural and communication: includes the realisation of the need of internally displaced persons in selfexpression, preservation of cultural, ethnic, religious and linguistic identity, participation in the development of the social capital of the community as a common resource, free communication with members of the host population, non-discrimination;

3) socio-economic: reflects the need for internally displaced persons in the provision of housing, income, workplace and the exercise of rights in this part, guaranteed by both local authorities and state guarantees and obligations;

4) socio-political: reflects the realisation of the need for the participation of internally displaced persons in the political life of the community, ensuring the right to participate in elections; the development, adoption and implementation of decisions, including those concerning the resolution of IDPs' problems; as well as the right to receive state support and assistance.

At the same time, it is assumed that each of the four components of the model systematically affects the level of social integration of the internally displaced person, who is subjective in expression. The level of integration has two basic parameters: social well-being and social exclusion.

The development among Ukrainian researchers of the concept of 'social well-being' was carried out by the sociologists E. Golovakha and N. Panina (1997), and was presented as a personal integral indicator of the satisfaction or dissatisfaction of a person with the fulfilment of their basic needs (social, psychological, cultural, material, economic, labour) and his position in the system of social relations. Knowledge about subjective well-being in foreign studies is also complemented by theories of social well-being, which is determined by an assessment of the personality, the quality of social ties, and integration into society (Huppert, Marks, Clark 2007).

The social exclusion indicator reflects the opposite of social integration. That is, the degree of expression of a person's social exclusion, his alienation from social life and communication, psychological loneliness, and a sense of 'isolation' from others. Questions of loneliness are presented in the research by D.W. Russell and M.L. Ferguson (UCLA Loneliness Scale 1978), which measures personal feelings of loneliness and feelings of social isolation. This technique was used in our study in the Russian adaptation (Fetiskina, Kozlova, Manuilova 2002).

To obtain statistically expressed data, a set of techniques was used: the Coping Test by R. Lazarus and S. Folkman in the Russian adaptation (Kryukova, Kuftyak, Zamyshlyayeva 2007); Express diagnostics of the level of social isolation of the person (Russell, Fergusson 1978); Integral index of social well-being test (Golovakha, Panina 1997); Russian adaptation of the English Questionnaire Hardiness Survey (Leontiev, Rasskazova 2006), and the authors' questionnaire 'Integrity Scale' containing 30 questions for each component of the model.

The statistical processing of the data was carried out using a specialised package for social research, SPSS 22 methods of correlation, factor and variance analysis (Fisher's criterion).

The model presented can be used to reflect the understanding and experience of the social integration of internally displaced persons in the host community through the organisation of discourse in the relevant local communities, namely internally displaced persons, local community members, civil society members 
providing assistance to IDPs in need, and local authorities. On the other hand, the model can be a tool to reflect the current situation in the local community in the direction of social integration. Local authorities may include programmes, actions and other events that will serve to promote the effective integration of internally displaced persons into local communities.

The number of internally displaced persons from the east of Ukraine who participated in the study was 201: 60\% were from the Donetsk region, and 40\% were from the Luhansk region; 35 were men (17.4\%), and 166 were women $(82.6 \%)$; their ages were from 26 to 72 .

\subsection{Research results}

After conducting a correlation and factor analysis, the theoretical model of social integration of IDP was refined, and the respective empirical model was validated. The model consists of four components (sociopsychological, cultural-communication, socio-economic, and socio-political) and an integral indicator (social well-being and social isolation), which affects the level of integration of the internally displaced person into the local community (Fedorenko 2018). A model of the study is presented in Figure 1.

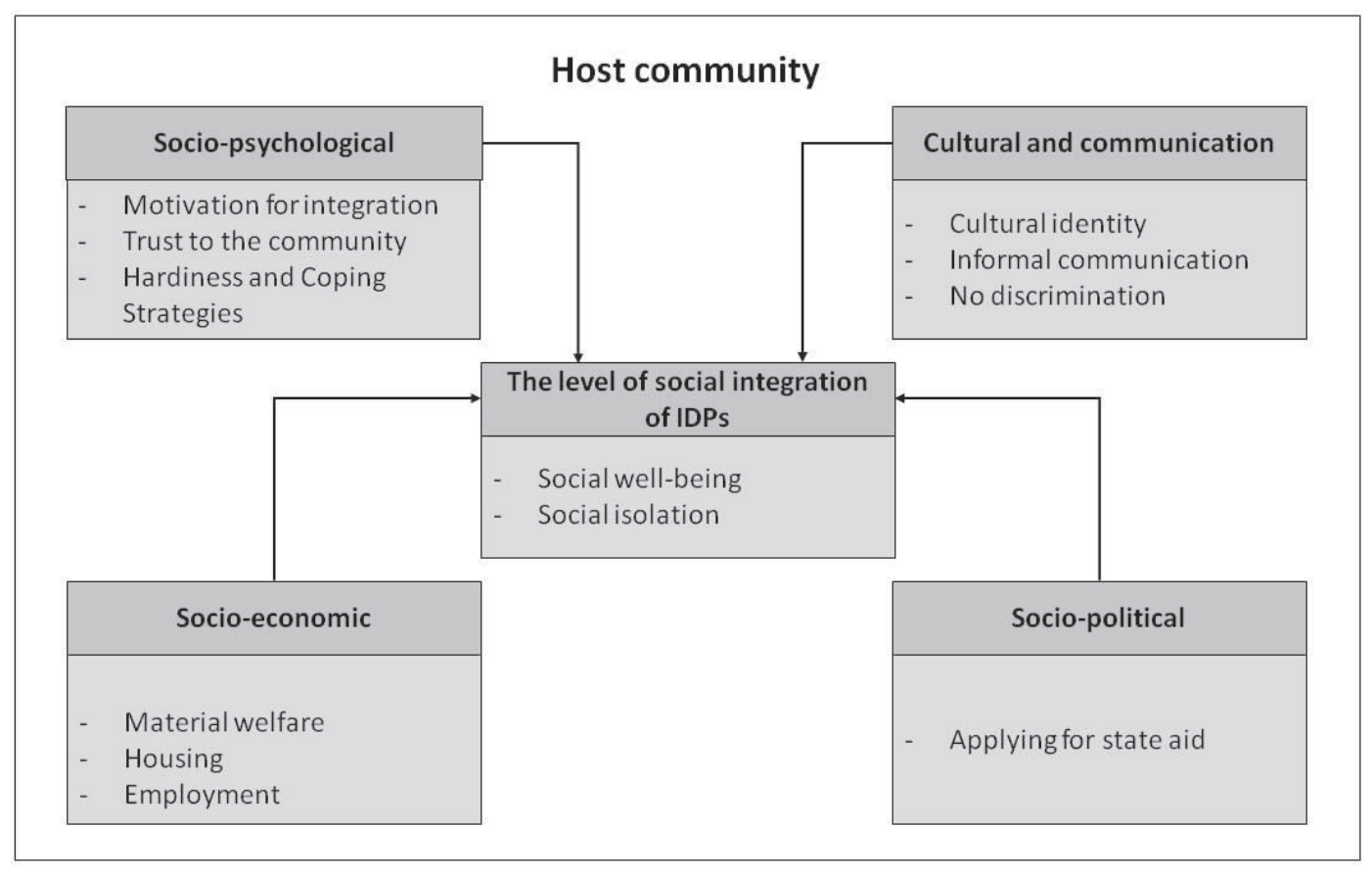

Figure 1. Model of social integration of internally displaced persons in the community.

Source: author's construction based on research.

Let us consider each component of the model separately.

The most evident indicator of the social and psychological component, according to Fisher's criterion, was the following indicator: 'desire/planning to return to the previous place of residence' $(F=3,687 ; p$ $<0,05)$. In other words, securing the exercise of the right to freedom of choice as to a possible return to the previous place of residence has proven to be the most significant. It also found that respondents who did not intend to return to their previous place of residence had the highest social well-being rates, and in contrast, respondents who were motivated to return after the conflict had the highest social isolation rates. This, in turn, may mean that the motivation to return automatically 'excludes' a person from social life, and serves as a kind of barrier to finding ways and means of integration into the new social context. 
It was found that the degree of social well-being of internally displaced persons depends on their awareness or long-term decision making, and the appearance of a sense of certainty about their future. According to the results obtained, this parameter is crucial for the level of integration as a whole (for social well-being $F=10,013 ; p<0.01$; for social isolation $\mathrm{F}=19,570 ; \mathrm{p}<0.01$ ). Accordingly, the highest indicators of social well-being are respondents who have a better idea of where their life is heading, the lowest values are those who do not.

An important parameter of local community integration is the social and psychological component of trust, as a subjective sense of belonging to others, which can only emerge in the absence of discrimination or stigma in the new community. Thus, it was found that social well-being is highest among those who do not attribute themselves in the community to a separate group of internally displaced persons, but on the contrary, try to take an active part in the community's social life, engage in social activities, etc.

The distribution of coping strategies and sustainability with respect to community trust indicates that sustainability and its components depend on the level of trust of internally displaced persons in the community. Summarising the findings, it was found that the greater the community's trust, the higher the hardiness indicator. However, the lowest hardiness figure is inherent in those who find it difficult to determine whether they have confidence in community members.

These results are to some extent logical, since hardiness as a psychological property can only be formed and developed if social security is available.

Instead, the highest values of social isolation $(\mathrm{F}=1,254 ; \mathrm{p}<0.05)$ were attained by respondents who were more likely to show social assistance in various forms of financial support, not proactive behaviour and participation.

Similar results have also previously been found in focus group studies (Fedorenko 2019). This type of internally displaced behaviour is tentatively referred to by us as 'consumer behaviour', which has the inherent lack of responsibility for one's own life in the new social conditions and for translating it into external factors (such as social assistance from the state).

The trends identified were corroborated by the established correlation between 'hardiness' metrics (including its 'commitment' and 'challenge' components) and individual 'coping strategies' ('distancing', 'escapeavoidance'). Yes, social well-being has direct significant correlations with hardiness $(r=0.536 ; p<0.01)$, control ( $r=0.478 ; p<0.01)$, commitment $(r=0.508 ; p<0.01)$, and challenge $(r=0.493 ; p<0.01)$; significant correlations with distancing $(r=-0.206 ; p<0.01)$ and escape-avoidance $(r=-0.233 ; p<0.01)$ were reversed. In other words, adaptive coping strategies and the active position of internally displaced persons in participating in community life have a positive effect on social well-being, and consequently on accelerating integration. Instead, the strategies of 'distancing' and 'escape-avoidance' in IDPs are manifested in the avoidance of contact with locals, an unwillingness to participate in local events, and deliberate distancing from the situation, which is generally reflected in the integral indicator of social isolation.

The next component of the analysis is cultural and communicative. It is based on the right to preserve one's cultural identity, as well as respect for the values, traditions, language and religion of the local population. Cultural identity differences have historical and socio-political roots in Ukraine, and this difference is often one of the main reasons for choosing a place of resettlement. Thus, the largest number of displaced persons moved to the nearest territorial communities with similar cultural values: 494,500 registered persons in the Donetsk region, 272,200 in Lugansk, 152,100 people in Kiev, and 131,000 people in the Kharkiv region. There are much fewer displaced persons in the western regions of Ukraine: about 3,000 people in the Volyn and Rivne regions, and about 2,000 in Ternopil, according to the analytical resource (Slovoidilo.ua 2019), based on information from the Ministry of Social Policy of Ukraine.

The study found that internally displaced persons who share the cultural values of the local community (including religious beliefs) have higher levels of social well-being $(\mathrm{M}=43.38)$, and those who do not, the contrary $(\mathrm{M}=37.00)$.

It is important to note that with the advent of migration processes in Ukraine, new words and terms that did not exist before have appeared in the lexicon of Ukrainians, such as 'separatists', which emphasise differences between 'them' and 'us', and exacerbate discrimination and prejudice. It was found that, in the presence of biased attitudes, the social well-being of IDPs decreased $(F=4,022 ; p<0.05)$, the same factor giving rise to a number of social bar- 
riers between IDPs and members of the host community: the refusal to rent housing from locals, discrimination by the local population, the restriction of access to state medical, cultural and social institutions, the restriction of rights in employment in the workplace, the violation of the law in the placement of children in kindergartens.

Instead, it was found that informal communication with the community contributing to the development of social capital in the new place of residence is an essential indicator of the IDP's social well-being. The survey results show that $12.94 \%$ of respondents do not communicate at all, or rarely communicate, with members of the host community, which increases the distance between them, and may impede social integration at the community level. A total of $13.43 \%$ communicate with approximately everyone, and $74.63 \%$ have close contact with the local population.

The next component of the analysis is socio-economic. The Guiding Principles on Internal Displacement (1998: Principle 22, paragraph b) state that internally displaced persons have the right to freely seek employment and participate in economic life. Among the surveyed respondents, 93.53\% are employed, $6.47 \%$ are unemployed, and $2.49 \%$ of respondents could not find a job or were on maternity leave or had reached retirement age.

The current financial situation of IDPs was found to affect their social well-being $(\mathrm{F}=27,095 ; \mathrm{p}<0.01)$ and social isolation $(\mathrm{F}=13,009 ; \mathrm{p}<0.01)$. Among those surveyed, the highest percentage $(45.27 \%)$ are those who lack money and can afford only the most necessary things, while those who are forced to save and have a difficult economic situation (27.36\%) and those who have all necessary means for comfortable life (27.36\%) are evenly distributed. Accordingly, a better financial status contributes to the social well-being of IDPs, and material hardship increases social exclusion in the community.

Features of the settlement of the housing issue by internally displaced persons were clarified. It turned out that the level of social well-being depends on the type of housing in which IDPs live. The highest rate was recorded for those who purchased their own housing, at 12.44\% $(\mathrm{M}=44.76)$, and they also had the lowest social isolation figures $(M=54.64)$. On the other hand, the lowest indicator of social well-being was found in citizens living in displaced dwellings (dormitories, sanatoriums, children's camps), at $11.44 \%(\mathrm{M}=37.83)$, and the highest level of social isolation $(\mathrm{M}=66.48)$.

It has been found that social well-being depends on IDPs' satisfaction with their housing in their new place of residence. Thus, for social well-being $(\mathrm{F}=6,967 ; \mathrm{p}<0.01)$ and social isolation $(\mathrm{F}=5,745 ; \mathrm{p}<0.01)$, housing satisfaction is significant.

The most indicative trends by type of IDP employment were also found. The highest level of social wellbeing is typical of business owners $(M=45.7)$, followed by hired workers $(M=43.02)$, government employees $(\mathrm{M}=41.30)$, and the self-employed $(\mathrm{M}=39.75)$, and the lowest level of social well-being is among the unemployed $(M=33.4)$. The highest level of social isolation is typical of those who have maternity leave $(M=69.9)$, then self-employed $(M=68.25)$, and pensioners $(M=67.27)$, and the lowest is for civil servants $(M=56.3)$. Thus, the occupation and type of employment affect qualitative characteristics of IDPs' social integration.

The next component of the analysis is socio-political. We envisaged that exercising the right to participate in political decision-making and elections is a significant indicator of the social integration of IDPs. However, it was found that exercising this right was not a priority for them (for social well-being $[\mathrm{F}=0.190$; $\mathrm{p}>0.9]$ and social isolation [ $\mathrm{F}=1.765 ; \mathrm{p}>0.3])$. Equally, it is not a significant indicator of IDPs' involvement in the political life of the country as a whole, and of the community in particular for social well-being $(\mathrm{F}=1,820 ; \mathrm{p}>0.6)$ and social isolation $(\mathrm{F}=2,318 ; \mathrm{p}>0.2)$.

Instead, knowledge of their rights in the displacement situation has a positive effect on the level of IDPs' well-being, in particular a high level of awareness of alternative sources of assistance from the state, the community, NGOs, and so on, is inversely proportional to the level of social isolation ( $F=4,846 ; p<0,1)$.

At the same time, the following dependence was found: those respondents who regularly receive state aid (payments, benefits, etc) do not display activity in the life of the new community. This is manifested in the high level of social isolation ( $\mathrm{M}=70.00)$ and the choice of a strategy of 'shifting responsibility' to others. Accordingly, the level of social well-being is much lower in those who are constantly seeking state aid, and highest in those who have never sought it $(\mathrm{F}=6.088$; $\mathrm{p}<0.1)$. 
The next step was to identify levels of integration of internally displaced persons and identify the conditions that affect them. Levels of integration were calculated using the formula IL $=(\mathrm{SW}+\mathrm{SI}) / 2$; $(\mathrm{Lmax}-$ Lmin) / 3, where IL = Integration Level, SW = Social Well-Being, SI = Social Isolation, and L = level; with the further conversion of the Integrity Scale to Low (1), Medium (2) and High (3).

As a result, it was found that $12.9 \%$ of respondents have a low level of integration, $60.2 \%$ have an average level of integration, and $26.9 \%$ of respondents have a high level of integration. Thus, there is a rather positive tendency for the integration of internally displaced persons into host communities. At the same time, due to the analysis of variance (according to Fisher's criterion), the conditions that affect the level of IDP integration are previously identified. These data are shown in Table 1.

Table 1. IDPs' levels of social integration and the conditions they provide

\begin{tabular}{|c|c|}
\hline Levels & Conditions \\
\hline High & $\begin{array}{l}\text { - } \quad \text { lack of motivation to return to the previous place of residence } \\
\text { - } \quad \text { employment (availability of workplaces) } \\
\text { - } \quad \text { housing security and overall housing satisfaction } \\
\text { - } \quad \text { high level of current financial status } \\
\text { - informal communication with community representatives } \\
\text { - } \quad \text { identity with the local population } \\
\end{array}$ \\
\hline Medium & 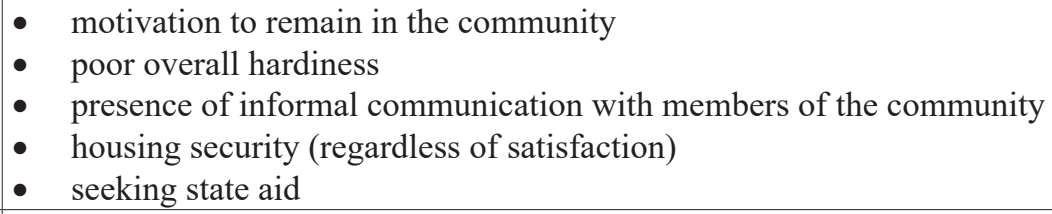 \\
\hline Low & $\begin{array}{l}\text { - lack of own housing } \\
\text { - lack of motivation to stay in the community } \\
\text { - } \quad \text { self-identification as 'migrants' } \\
\text { - lack of informal communication with community members } \\
\text { - } \quad \text { lack of identification with community members } \\
\end{array}$ \\
\hline
\end{tabular}

Source: author's construction based on research.

\section{Conclusion}

The research conducted has revealed the most important conditions that facilitate the social integration of internally displaced persons in host communities.

The most significant of these conditions are those related to the realisation of human rights in free movement and the choice of a new place of residence. The study has shown that where the choice is made independently, without outside interference (for example, by social services), the motivation for integration, as well as for non-return, is high. Most internally displaced persons no longer plan to return to their previous place of residence after the end of hostilities, they have exercised sufficiently their right to employment and settled housing. Also, the more IDPs identify with the local population and become actively involved in community life, without assistance or government support, the greater their level of integration. As a result of full integration, the status of 'internally displaced person' should be eliminated, as privileges would be impractical, and on the contrary, would be regarded as a factor separating migrants from the local population.

However, according to the survey, there is still a proportion of IDPs who do not have their own housing, have problems with employment, and need state support. Accordingly, they have a lower level of integration. Therefore, it is relevant to conduct further research to develop the necessary system of measures to ensure that the state's social policy on internally displaced persons is aimed at supporting migrants who remain at a lower level of integration. 


\section{References}

Ager, A., Strang, A. (2008). Understanding Integration: A Conceptual Framework. Journal of Refugee Studies, Vol. 21 , № 2.

Al-Sharmani, M. (2004). Refugee Livelihoods: Livelihood and Diasporic Identity Constructions of Somali Refugees in Cairo. Geneva: UNHCR. Available at: https://www.unhcr.org/research/working/410909d54/refugee-livelihoodslivelihood-diasporic-identity-constructions-somali.html

Approval of the Strategy for Integration of Internally Displaced Persons and Implementation of Long-Term Solutions for Internal Displacement for the Period up to 2020 dated November 15, 2017, No. 909 p. The Cabinet of Ministers of Ukraine. Available at: https://zakon.rada.gov.ua/laws/show/909-2017-\%D1\%80

Castles, S. (2001). Global trends and problems. International migration at the beginning of the 21st century: global trends and problems. International Journal of Social Sciences, № 032, p. 27-42. Available at https://doi.org/10.1111/issj.12185

CEDOS think tank. (2018). Internally displaced persons integration index. Available at: https://cedos.org.ua/en/vpointegration-index.

Duncan, C. R. (2005). Unwelcome guests: Relations between internally displaced persons and their hosts in North Sulawesi, Indonesia. Journal of Refugee Studies, Vol. 18(1), p. 2546. Available at: https://doi.org/10.1093/jrs/18.1.25

Fedorenko, O. (2018). The theoretical model of social integration of internally displaced persons in the community. Bulletin of Taras Shevchenko National University of Kyiv. Social work, Vol. 1(3), p. 17-22.

Fedorenko, O. (2019). Features of the social integration process of internally displaced persons with different types of settlement (based on the focus-groups series). Journal of Scientific Study Molodyvcheny, № 2 (66), p. 534-540.

Fetiskin, N., Kozlov, V., Manuylov, G. (2002). Express diagnostics of the level of social isolation of a person (D. Russell and M. Fergusson). Socio-psychological diagnosis of personality development and small groups. Moscow, Russia, p. 24-25.

Global report of Internal displacement. (2018). Available at: https:/www.internal-displacement.org/global-report/grid2018/.

Golovakha, E., Panina, N. (1997). Integral index of social well-being (IISS): Design and application of a sociological test in mass surveys. Kiev, Ukraine. Institute of Sociology, National Academy of Sciences of Ukraine.

Guiding Principles on Internal Displacement. (1998). Available at: https://www.unhcr.org/protection/idps/43ce1cff2/ guiding-principles-internal-displacement.html

Huppert, F., Marks, N., Clark, A. (2007). Personal and Social Well-being Module: for the European Social Survey. Round 3. Available at: http://www.cambridgewellbeing.org/Files/Well-being-Module_Jun06.pdf

International Organization for Migration. (2017). National monitoring system report of situation of the internally displaced persons june 2017. Available at: http://iom.org.ua/sites/default/files/nms_report_june_2017_eng_screen_2.pdf

Jacobsen, K. (2001). The Forgotten Solution: Local Integration for Refugees in Developing Countries. New Issues in Refugee Research. Working Paper No. 45. Available at: https:/www.unhcr.org/research/working/3b7d24059/ forgotten-solution-local-integration-refugees-developing-countries-karen.html

Kryukova, T., Kuftyak, E. (2007). Questionnaire of coping methods (adaptation of the WCQ technique). Journal of the Practical Psychologist, Vol. 3 p. 93-112.

Leontiev, D., Rasskazova, E. (2006). Test of hardiness. Moscow, Russia.

Migration data portal. (2020). Migration integration. Available at: https://migrationdataportal.org/themes/migrant-integration.

Ministry of Social Policy of Ukraine. (2020). Available at: https://www.msp.gov.ua/news/18256.html.

Nadareishvili, M., Tsakadze, V. (2008). Survey about Housing and Social-Economical Conditions of Internally Displaced People: Study of conditions of IDPs from private settlements and comparing them to conditions of IDPs from collective centers. Report. Tbilisi.

On ensuring the rights and freedoms of internally displaced persons Law of Ukraine dated October 20. (2014). No. 1706-VII. Verkhovna Rada of Ukraine. Available at: https://zakon.rada.gov.ua/laws/show/1706-18

Parsons, T. (1972). General review. American Sociology: Perspectives. Problems. Methods. Moscow, Russia.

Refugee Convention. (1951). Available at: https:/www.un.org/ru/documents/decl_conv/conventions/refugees.shtml

Russell, D., Peplau, L. A., Ferguson, M. L. (1978). Developing a measure of loneliness. Journal of Personality Assessment, № 42, p. 290-294.

SLOVOIDILO analytic resource. (2019). Dynamics of migration in Ukraine where the largest number of migrants registered. Available at: https://www.slovoidilo.ua/2019/12/27/infografika/suspilstvo/dynamika-mihracziyi-ukrayinizhyve-najbilshe-zareyestrovanyx-pereselencziv.

United Nations General Assembly. (2017). Protection of and assistance to internally displaced persons. Available at: https://undocs.org/en/A/C.3/72/L.46/Rev.1

United Nations of Ukraine. (2019). Inclusion of Internally Displaced Persons. Available at: http://www.un.org.ua/ images/documents/4717/Briefing\%20Note\%20Inclusion\%20of\%20Internally\%20Displaced\%20Persons-eng.pdf.

Volosevych, I., Kostiuchenko, T. (2018). Desk research of the surveys of IDPs. Available at: http://www.unhcr.org/ua/ wp-content/uploads/sites/38/2018/05/gfk_unhcr_desk_report_final.pdf.

World Migration report. (2000). Available at: https://publications.iom.int/system/files/pdf/wmr_2000_edited_0.pdf 


\title{
PERKELTUJU ASMENU ŠALIES VIDUJE SOCIALINĖS INTEGRACIJOS LYGIAI PRIIMANČIOSE BENDRUOMENÉSE
}

\author{
Olena Chuiko, Oleksandra Fedorenko \\ Taraso Ševčenkos nacionalinis universitetas Kijeve (Ukraina)
}

\section{Santrauka}

Straipsnyje aprašomi šalies viduje iš Ukrainos rytų perkeltų asmenų socialinės integracijos į priimančiają bendruomenę empirinio tyrimo rezultatai. Tyrimu siekta apibūdinti šalies viduje perkeltų asmenų socialinès integracijos lygị priimančiojoje bendruomeneje. Tyrimo imtị sudaro 201 šalies viduje perkeltas asmuo iš Ukrainos rytų (60 proc. - iš Donecko ir 40 proc. - iš Luhansko sričių). Svarbi veiksmingos integracijos i bendruomenes sąlyga - teisès dalyvauti visuose svarbiuose sprendimų priėmimo procesuose užtikrinimas.

Sukurtas autorių empirinis socialinės integracijos modelis, kurị sudaro keturi komponentai (socialinispsichologinis, socialinis-ekonominis, kultūrinis-komunikacijos, socialinis-politinis) ir vienas neatsiejamas rodiklis, turintis įtakos integracijos lygiui. Pastarasis turi du pagrindinius parametrus: socialinè gerovè ir socialinè izoliacija. Šis modelis grindžiamas žmogaus teisių apsaugos koncepcija, sprendžiant perkeltų asmenų problemą ir sudarytas įtraukiant keturis pagrindinius segmentus, kurie atskleidžia žmogaus teisių igyvendinimo sritis perkèlimo ị naujas vietines bendruomenes situacijose.

Tyrimo rezultatai atskleidè, kad daugelio apklaustų šalies viduje perkeltų asmenų integracijos lygis vidutinis (121 respondentas) ir aukštas (54 respondentai). Atitinkamai tik 26 apklaustieji menkai integruoti. Aukšto integracijos lygio šalies viduje perkeltų asmenų dalis nesiekia valstybès pagalbos ir mano, kad esamas jų statusas - šalies viduje perkelti asmenys - netinkamas. Teigiamos socialinės integracijos sąlygos yra pačių šalies viduje perkeltų asmenų aktyvumas, ịsitraukimas ị bendruomenès gyvenimą, ypač neformali komunikacija su bendruomenès atstovais, tai savo ruožtu lemia bendruomenės pasitikejjimą. Pasitikejjimas bendruomene, tapatinimasis su jos nariais, motyvacija likti šioje bendruomenèje yra teigiamos gerovès, tiesiogiai veikiančios integracijos lygị, rodikliai. Tuo tarpu būsto trūkumas, ryšys su vietos gyventojais, neoficialios komunikacijos būdai, ,,priklausomybė“ nuo valstybės pagalbos (įvairios jos apraiškos) yra pagrindiniai žemo integracijos lygio priimančiojoje bendruomenejje veiksniai.

PAGRINDINIAI ŽODŽIAI: socialine integracija, integracijos lygis, šalies viduje perkeltieji asmenys, priimančioji bendruomene.

JEL KLASIFIKACIJA: I 31, I 38, O 15, R 23

Received: 2020-04-10

Revised: 2020-04-29

Accepted: 2020-05-05 